\title{
CEREBROSIDE SYNTHESIS AND HYDROLYSIS IN A NEUROLOGICAL MUTANT MOUSE (MSD)
}

ANTOINETTE BRENKERT, RAMESH C. ARORA, NORMAN S. RADIN, HANS MEIER, AND ANN D. MACPIKE

Mental Health Research Institute, University of Michigan, Ann Arbor, Mich. 48104, and The Jackson Laboratory, Bar Harbor, Maine 04609 (U.S.A.)

(Accepted July 7th, 1971)

\section{INTRODUCTION}

The sex-linked mutation, myelin synthesis deficiency of the mouse (gene symbol, $m s d)$, causes a severe defect in brain myelination ${ }^{6,7}$. Myelin components, particularly galactosyl ceramide*, are greatly reduced in concentration or absent. Since the primary genetic defect might be an inability to make galactocerebroside, by galactosylation of ceramide $^{8,9}$, we assayed mutant and normal brains for the enzyme which carries out this step. For comparison, we assayed the brains as well for the glucosyltransferase which makes glucocerebroside and for the galactosidase which hydrolyzes galactocerebroside. Glucocerebroside appears to be an intermediate in ganglioside metabolism $^{1,15}$, which is normal in the mutant ${ }^{7}$. The hydrolase was of interest because the lack of galactocerebroside could be due to overactivity of the hydrolase rather than insufficient synthesis.

The activities of the 3 enzymes follow quite different patterns of change with age in rats ${ }^{3,4}$, and it seemed important to compare these changes in normal and mutant mice. Such an approach might allow one to distinguish between primary and secondary abnormalities.

MATERIALS AND METHODS

Tissues

The mice were bred, sacrificed, and dissected at The Jackson Laboratory, and the brains were shipped in dry ice and stored at $-75^{\circ} \mathrm{C}$. The brains were stored at $-60^{\circ} \mathrm{C}$ for $67-423$ days before shipment.

* Nomenclature: Galactosyl ceramide is galactocerebroside; glucosyl ceramide is glucocerebroside. Both lipids are commonly called cerebroside. 
Assay procedures

The procedures for the transferases are described by Brenkert and Radin 1 . Higher levels of tissue ( $2 \mathrm{mg}$ dry weight) were used here. The assays were carried out the next day after lyophilizing the tissue.

For the assay of cerebroside galactosidase, $2 \mathrm{mg}$ of lyophilized brain was used rather than the purified enzyme ${ }^{3}$. This results in dilution of the radioactive cerebroside by endogenous cerebroside, an effect which increases with age as cerebroside accumulation occurs. Since, in the oldest animals, the amount of endogenous substrate was only about one-fourth the weight of radioactive substrate, the resultant error should not be serious. An improved substrate preparation and work-up procedure were used ${ }^{12}$.

\section{RESULTS}

\section{Galactocerebroside biosynthesis}

Normal and affected mice exhibit two widely differing activities at all ages studied (Fig. 1). The normal mice show changes with age that greatly resemble those of rats, with transferase activity rising rapidly to about 17 days, and decreasing rapidly thereafter ${ }^{4}$. The mutant mice, which are usually but not always identifiable by clinical abnormalities at 8 or 9 days, show a much smaller rise in activity. The

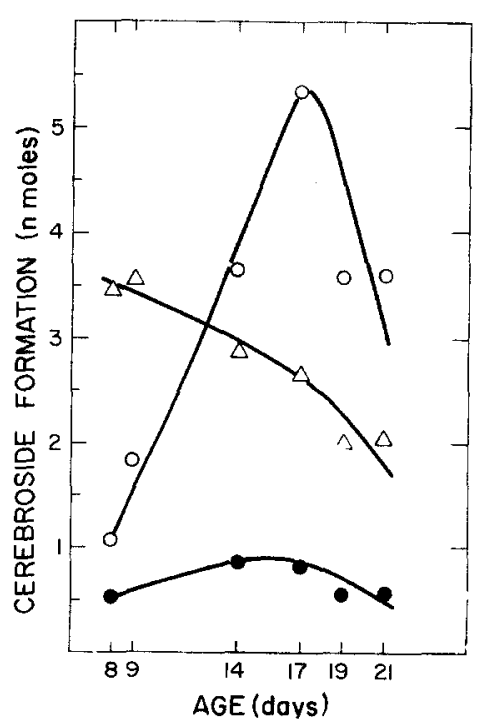

Fig. 1. Changes with age in hexosyltransferase activity. $O=$ galactosyltransferase in normal mice. - galactosyltransferase in $\mathrm{msd} / \mathrm{Y}$ mice. $\Delta=$ glucosyltransferase in both groups. Assay medium for galactosyltransferase: $0.2 \mathrm{ml}$ containing $0.1 M$ Tris $\mathrm{pH} 7.4,15 \mathrm{~m} M \mathrm{MnCl}, 2 \mathrm{~m} M$ EDTA, $1 \mathrm{~m} M$ dithiothreitol, $5 \mathrm{~m} M$ nicotinamide, $0.16 \mathrm{mM}{ }^{14} \mathrm{C}$-UDPgalactose, $2 \mathrm{mg}$ dry brain, $0.2 \mathrm{mg}$ hydroxy ceramide; incubated $2 \mathrm{~h}$ at $37^{\circ} \mathrm{C}$. Assay for glucosyltransferase is similar, but ${ }^{14} \mathrm{C}$-UDPGlc is the labeled compound, nonhydroxy ceramide is used, and $2 \mathrm{mM}$ ATP is included. 


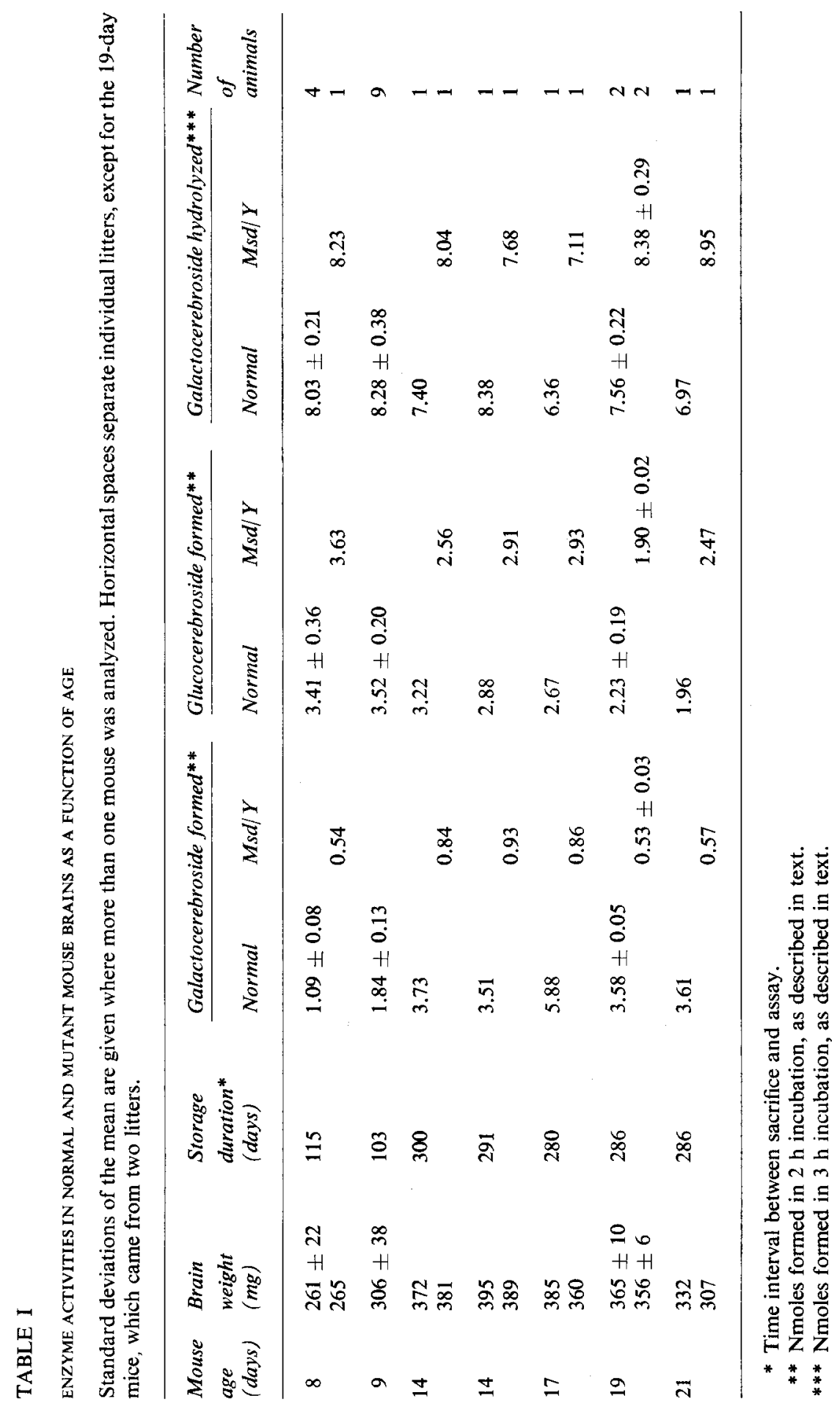


activities in the youngest mutants are $50 \%$ of normal and, in the 17-day mutants, $15 \%$ of normal.

While only a single $m s d$ brain was available at the 8-day time point, previous assays of the galactosyltransferase using a different assay procedure yielded a similar difference between three 9-day-old $m s d$ mice and 3 littermates.

\section{Glucocerebroside biosynthesis}

There appears to be no difference in glucosyltransferase activities between the two genotypes (Table I). Both show a rather steady decrease in activity with age (Fig. 1). A less continuous decrease had been noted in rats but the overall pattern is comparable ${ }^{4}$. The ratio of galactosyl- and glucosyltransferase activities at each age is quite similar in both rats and mice, i.e., low at 8 days and high after 16 days.

\section{Galactocerebroside galactosidase}

There is little difference between normal and affected mice at all ages (Table I). The lower activities seen in older normal mice are presumably the result of the use of whole brain, rather than purified enzyme, since there is only negligible dilution of the radioactive substrate in the $m s d$ samples.

\section{Test for the presence of an inhibitor}

We thought that a possible explanation for the low galactosyltransferase activity in the mutants might be the presence in mutants of an inhibitor in high concentration.

\section{TABLE II}

SYNTHESIS OF GALACTOSYL CERAMIDE BY MIXTURES OF BRAIN POWDERS FROM NORMAL AND MUTANT MICE The assay procedure is described in Fig. 1.

\begin{tabular}{|c|c|c|c|}
\hline \multicolumn{3}{|l|}{ Powder used } & \multirow{2}{*}{$\begin{array}{l}\text { Cerebroside formed } \\
\text { (nmoles) }\end{array}$} \\
\hline $\begin{array}{l}\text { 17-day } \mathrm{msd} / \mathrm{Y} \\
(\mathrm{mg})\end{array}$ & $\begin{array}{l}\text { 17-day normal } \\
\text { (mg) }\end{array}$ & $\begin{array}{l}\text { 8-day normal } \\
(\mathrm{mg})\end{array}$ & \\
\hline & 1 & & 2.87 \\
\hline & 2 & & 4.21 \\
\hline 1 & & & 0.51 \\
\hline 2 & & & 0.66 \\
\hline \multirow[t]{5}{*}{1} & 1 & & 2.45 \\
\hline & & 1 & 0.53 \\
\hline & & 2 & 1.00 \\
\hline & 1 & 1 & 2.65 \\
\hline & 1 & & $0.22 *$ \\
\hline \multirow[t]{2}{*}{1} & & & $0.26^{*}$ \\
\hline & & 1 & $0.11^{*}$ \\
\hline
\end{tabular}

\footnotetext{
* These incubations were run without added hydroxy ceramide acceptor.
} 
This possibility was tested by mixing normal and affected mouse brain and comparing the activity with similar amounts of separate brain powders (Table II). The comparison is complicated by the lack of linearity with respect to tissue weight: doubling the weight of normal brain yields only $47 \%$ more activity in 17 -day mice, and $89 \%$ more at 8 days. In mutant mice 17 days old, the increase is only $29 \%$.

The mixture of $1 \mathrm{mg}$ each of 17-day normal and mutant mouse brain gives an activity ( $2.45 \mathrm{nmoles}$ ) that is only $72 \%$ of the activity expected from the sum of the $1 \mathrm{mg}$ activities $(2.87+0.51=3.38 \mathrm{nmoles})$. This would indicate the presence of some inhibitory compound, although its effect does not seem large enough to account for the difference between the two groups. If the activity of the mixture is compared with the average of the two activities at the $2 \mathrm{mg}$ level $((4.21+0.66) / 2=2.44)$, there is no evidence of an inhibitor. However, the poor linearity in all preparations suggests that there exists normally some inhibitor in all brains.

A similar comparison between normal 8-day and 17-day mice (middle of Table II) shows that the mixture has $78 \%$ of the expected activity, again indicating the presence of a natural inhibitor. It seems unlikely that the low activity seen in young mice is due to a high concentration of the inhibitor.

The activities observed without addition of exogenous acceptor substrate (bottom of Table II) reflect utilization of endogenous nonhydroxy ceramide 4 .

\section{Characterization of the galactosyltransferase in normal and mutant mice}

In the case of Krabbe disease, a disorder caused by a deficiency of galactocerebroside galactosidase ${ }^{14}$, the residual hydrolase activity in the affected individuals has an abnormal $\mathrm{pH} /$ activity curve, and the possibility exists therefore that the residual activity is due to a different enzyme. A similar explanation could be given for our finding that the mutant mice do not entirely lack the galactocerebroside synthesizing enzyme. To test this, we measured the $K_{m}$ of the transferase in 17-day-old mice of both genotypes with respect to binding of UDPGal. We found that the $K_{m}\left(5.7 \cdot 10^{-5}\right)$

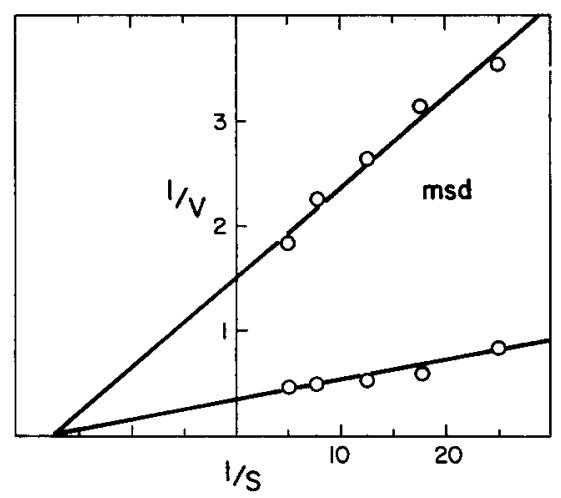

Fig. 2. Lineweaver-Burk plot relating galactocerebroside synthesis (nmoles) to UDPGal concentration $(\mathrm{mM})$. Conditions are the same as in Fig. 1 except that incubation is for $90 \mathrm{~min}$ using $1 \mathrm{mg}$ brain powder. Lower curve obtained with normal mice. 
was quite similar for both the $m s d / \mathrm{Y}$ and its normal littermate. A similar observation was made by Neskovic et al. ${ }^{10}$ with Jimpy and Quaking mice in an assay of the galactosyltransferase which forms psychosine. It is not yet known whether this is the same enzyme that forms galactocerebroside.

\section{DISCUSSION}

In an ongoing study 4 we have obtained evidence that glial and neuronal cell preparations, given the labeled substrates, can hydrolyze and synthesize galactocerebroside. The synthetic activity in neurons is somewhat lower than in glia, but still appreciable. These findings are supported by the report of Norton and Turnbull ${ }^{11}$ and of Raghavan and Kanfer ${ }^{13}$, who found galactocerebroside in isolated axonal and neuronal preparations.

An assay of whole brain must therefore reflect the synthetic capacity of neurons as well as glia. Our present findings (Fig. 1) can thus be explained to mean that the mutant mice $(m s d / Y)$ contain little galactocerebroside synthesizing ability in their non-neuronal cells, but normal activity in their neurons. At 8 days of age it appears from this hypothesis that as much as $50 \%$ of the normal observed transferase activity derives from neurons; at 17 days, the neuronal activity is increased moderately but the glial activity is increased considerably, so as to give a ratio of about $7: 1$.

This interpretation also explains the presence of some galactosyltransferase activity (toward sphingosine) in Jimpy and Quaking mice ${ }^{10}$. It is consistent with our observation (Table II) that the synthesis of galactocerebroside from endogenous ceramide is the same in both mutant and normal mice. Apparently the synthesis seen in the absence of added ceramide is due primarily to the enzyme in neurons, rather than in glia. Costantino-Ceccarini and Morell ${ }^{5}$ have recently obtained data rather similar to ours with Quaking mice, finding low galactosyl ceramide synthesizing ability in the mutants at every age. It is thus possible that Quaking mice, like $\mathrm{msd} / \mathrm{Y}$ mice, contain galactosyltransferase primarily in their neurons.

As part of our study, we examined a litter of two Jimpy mice (Ta jp/Y) and compared them with their two normal littermates $(++/ Y), 17$ days old. The normal brains exhibited activities of 5.06 nmoles galactocerebroside formed in $2 \mathrm{~h}$, and the mutants exhibited 0.77 nmoles formation. These activities were very close to those found with $m s d / Y$ mice (Table I) and were included in Fig. 1. The possibility exists that $m s d$ is an allele of $j p^{7}$. There was also noted a strong resemblance between the two mutants in the other two enzymes studied: glucosyltransferase activity was 2.76 nmoles in the normals and 2.41 in the $j p$ mice; galactosidase activity was 6.99 nmoles in the normals and 8.40 nmoles in the $j p$ mice (compare Table I). It is thus likely that Jimpy mice, like msd and Quaking mice, contain a normal concentration of galactocerebroside synthesizing enzyme in their neurons but little in their glia.

Our use of brains which had been stored a long time, for various periods, introduces some question about the assay validity. However, our age curves match those seen with freshly removed rat brains ${ }^{4}$ and are fairly similar to those obtained with Quaking mice and their littermates ${ }^{5}$. The differences between normal and mutant 
mice were observed also in mouse brains which were shipped promptly after removal.

The question of which is the primary genetic defect in mice with the mutation, $m s d$, as in the other neurological syndromes exhibiting abnormal myelination, remains open. It does not appear likely that myelin-forming cells are markedly absent, since the galactocerebrosidase concentration is approximately normal. There is a small decrease in cerebroside galactosidase activity in Quaking mice, but not in Jimpy mice $^{2}$. In the latter mice, the enzyme appears to be somewhat more readily solubilized or dispersed but this may be a secondary phenomenon.

\section{SUMMARY}

Three enzymes related to myelin and ganglioside metabolism in the brains of normal and mutant $(m s d / Y)$ mice were compared through the ages 8-21 days old. No difference is seen in the glucosyltransferase which makes glucocerebroside or in the galactosidase which hydrolyzes galactocerebroside. However, the galactosyltransferase which makes galactocerebroside is markedly decreased in the mutants. The difference is most pronounced at 17 days, which is the age of maximal normal activity $(15 \%$ of normal); it is $50 \%$ of normal in 8 -day mice.

This variation with age is interpreted to mean that the galactosyltransferase in neurons is normal in both genotypes, but somewhat defective in the glia of $\mathrm{msd} / \mathrm{Y}$ mice.

The affinity of the enzyme for its nucleotide substrate, UDPGal, is the same in normal and affected animals. Mixing experiments indicate that the difference in enzyme activities is not due primarily to the presence of an endogenous inhibitor.

A comparison of Jimpy mice and normal littermates 17 days old reveals enzymatic relationships similar to those seen in 17-day $m s d$ and normal mice.

\section{ACKNOWLEDGEMENTS}

This work was supported in part by Grants NS 06448 and NS 03192 from the National Institute of Neurological Diseases and Stroke, a grant from the National Genetics Foundation, Inc., and a grant from the Health Research Fund of Schenectady.

\section{REFERENCES}

1 Basu, S., KaUfman, B., AND Roseman, S., Enzymatic synthesis of ceramide-glucose and ceramidelactose by glycosyltransferases from embryonic chick brain, J. biol. Chem., 243 (1968) 5802-5804.

2 BowEN, D. M., AND RADIN, N. S., Hydrolase activities in brain of neurological mutants : cerebroside galactosidase, nitrophenyl galactoside hydrolase, nitrophenyl glucoside hydrolase, and sulfatase, J. Neurochem., 16 (1969) 457-460.

3 Bowen, D. M., AND RADIN, N. S., Cerebroside galactosidase: a method for determination and a comparison with other lysosomal enzymes in developing rat brain, J. Neurochem., 16 (1969) 501-511.

4 Brenkert, A., AND Radin, N. S., Synthesis of galactosyl ceramide and glucosyl ceramide by rat brain: assay procedures and changes with age, Brain Research, 36 (1972) 183-193. 
5 Costantino-Ceccarini, E., AND Morell, P., Quaking mouse: in vitro studies of brain sphingolipid biosynthesis, Brain Research, 29 (1971) 75-84.

6 MeIER, H., AND DiCKIE, M. M., A neurological mutation of the mouse with a deficiency of myelin synthesis, Abstr. 2nd Meeting Int. Soc. Neurochem., Milan, (1969) 287.

7 Meier, H., AND MaCPike, A. D., A neurological mutation (msd) of the mouse causing a deficiency of myelin synthesis, Exp. Brain Res., 10 (1970) 512-525.

8 Morell, P., Costantino-Ceccarini, E., and Radin, N. S., The biosynthesis by brain microsomes of cerebrosides containing nonhydroxy fatty acids, Arch. Biochem. Biophys., 141 (1970) 738-748.

9 Morell, P., AND Radin, N. S., Synthesis of cerebroside by brain from uridine diphosphate galactose and ceramide containing hydroxy fatty acid, Biochemistry, 8 (1969) 506-512.

10 Neskovic, N., Nussbaum, J. L., AND Mandel, P., A study of glycolipid metabolism in myelination disorder of Jimpy and Quaking mice, Brain Research, 21 (1970) 39-53.

11 Norton, W. T., And Turnbull, J. M., The isolation and lipid composition of a myelin-free axon-enriched fraction from the CNS, Fed. Proc., 29 (1970) 472.

12 Radin, N. S., AND Arora, R. C., A simplified assay method for galactosyl ceramide $\beta$-galactosidase, J. Lipid Res., 12 (1971) 256 257.

13 Raghavan, S., AND Kanfer, J. N., Compositional studies on ceramide galactoside of enriched glial and neuronal cell fractions from rat brain, Trans. Amer. Soc. Neurochem., 2 (1971) 101.

14 Suzuki, K., AND SuzUKI, Y., Globoid cell leucodystrophy (Krabbe's disease): deficiency of galactocerebroside $\beta$-galactosidase, Proc. nat. Acad. Sci. (Wash.), 66 (1970) 302-309.

15 Tamai, Y., And Yamakawa, T., Study on glucocerebroside in Tay-Sachs brain, Jap. J. exp. Med., 39 (1969) 85-93. 